\title{
Effect of a mixture of steam-flaked corn and soybeans on health, growth, and selected blood metabolism of Holstein calves
}

\author{
Y. Q. Zhang, ${ }^{*} †$ D. Ch. He,† and Q. X. Meng*1 \\ ${ }^{*}$ College of Animal Science and Technology, State Key Laboratory of Animal Nutrition, China Agricultural University, Beijing 100193, P. R. China \\ †Institute of Animal Husbandry and Veterinary Science, Shanxi Academy of Agricultural Science, Taiyuan 030032, P. R. China
}

\begin{abstract}
The objective of the experiment was to evaluate the effects of steam-flaked corn grains and soybeans on calf health, growth, and selected blood parameters. Holstein bull calves $(\mathrm{n}=30$, approximately $7 \pm 3 \mathrm{~d}$ of age) were purchased from local dairy farms and offered milk, starter diets, and hay, and were then assigned to the experiment at $21 \pm 3 \mathrm{~d}$ of age. Calves were blocked into 3 treatments by birth date and body weight and randomly assigned to receive fresh milk and a commercial pelleted starter containing extruded corn and soybeans (ECS), steam-flaked corn and soybeans (SFCS), or ground corn and soybeans (GCS). The experiment was conducted with calves from 3 to $13 \mathrm{wk}$ of age. Body weight, calf starter intake, milk intake, total dry matter intake, and body structural growth were not significantly influenced by corn and soybean processing during the study; however, feed efficiency was significantly improved by the SFCS treatment. Average daily gain generally decreased during the weaning week for all treatments, but did not differ significantly among treatments. Health incidences for calves fed the SFCS starter were lower than those fed the other 2 treatments. The blood hematocrit was higher for calves fed the SFCS starter than for those fed the GCS and ECS starters during wk 6 to 11. The concentration of plasma $\beta$-hydroxybutyrate was higher for the calves fed the GCS and SFCS treatments than for those fed the ECS treatment during wk 6 to 13, but lower during wk 4 and 5. Plasma glucose concentrations decreased remarkably with increasing calf age but were not affected by corn and soybean processing. Plasma nonesterified fatty acids were influenced by calf age, and higher NEFA concentration was observed in the SFCS treatment than in the other 2 treatments during wk 5 to 9. Calves consuming the SFCS starter had similar average daily gain, milk intake, starter intake, total dry matter intake, and body structure, but had improved
\end{abstract}

Received June 29, 2009.

Accepted January 7, 2010.

${ }^{1}$ Corresponding author: qxmeng@cau.edu.cn feed efficiency when compared with animals consuming the GCS and ECS starters. The SFCS starter decreased incidence of diarrhea during the postweaning period and required less veterinary treatment. These data suggest that the steam-flaking of corn and soybeans can influence the growth performance and the selected blood parameters of calves and that, in this study, the extrusion of corn and soybeans had no beneficial effect on the growth performance of calves.

Key words: heat processing, Holstein calf, growth performance, blood parameter

\section{INTRODUCTION}

In calves, solid feed, especially concentrate or high carbohydrate diets, stimulates rumen microbial proliferation and VFA production and subsequently initiates rumen development (Harrison et al., 1960). Therefore, alterations in solid feed intake and its digestibility through a certain mechanical processing method may influence the rate and extent of rumen development. It was reported that grain processing methods and degree of processing influenced DMI and digestibility (Owens et al., 1997). The highest intake was found in diets containing dry-rolled grains, followed by whole, steamrolled, and steam-flaked grains, with finely ground grains resulting in the lowest feed intake (Owens et al., 1997). Crocker et al. (1998) reported that starch digestibility was the highest in steam-flaked grains, followed by finely ground, and then dry-rolled grains, and was the lowest in whole grains; however, this is not always the case (Reis and Combs, 2000). Feeding raw roasted or conglomerated sorghum grain to calves resulted in no effects on calf performance or rumen and blood metabolites (Abdelgadir and Morrill, 1995). However, Lesmeister and Heinrichs (2004) reported that rumen development, blood VFA concentrations, and ruminal propionate production were enhanced by incorporation of steam-flaked corn into the calf starter, but intake, feed efficiency, and growth were negatively influenced.

Most corn processing studies have been conducted using mature ruminants, and extrapolation of these results to immature ruminants may be limited because of 
known differences in digestion kinetics, microbial populations, and rumen capacity (Vazquez-Anon et al., 1993). Limited data are available concerning the processing of grains and protein feedstuffs influencing development of ruminal function in calves. Furthermore, much of the literature evaluating development of ruminal function has addressed characteristics associated with size or metabolic activity of the organ (Quigley et al., 1991). Therefore, this study was conducted to determine the effects of corn and soybean processing methods on feed intake, growth performance, and the changes of blood parameters in Holstein calves.

\section{MATERIALS AND METHODS}

\section{Animals and Treatment Diets}

Holstein bull calves $(\mathrm{n}=30)$ were purchased from local dairy farms at approximately $7 \mathrm{~d}$ of age and transported to the Huachen Dairy Farm in an eastern suburb of Beijing, China. All calves were visibly healthy and had been offered fresh milk, calf starter, and hay since they were introduced to the farm. After 2 wk of adaptation, when calves were visibly free of diseases and were ambulatory, they were assigned to 3 groups at the age of $21 \pm 3 \mathrm{~d}$ and fed fresh milk and calf starter pellets. Commercial calf starters (Table 1) were formulated to contain extruded corn and soybeans (ECS), steam-flaked corn and soybeans (SFCS), or ground corn and soybeans (GCS). Steam-flaked corn and soybeans were processed with a Roskamp Flaking Mill (model FX 1600-36, Roskamp Champion, Waterloo, IA) in Hebei Kaite Feed Mill Group (Hebei Xingtai, China). Processing conditions were set at 55 min of steam-conditioning and 0.8- to 1.2-mm flaking thickness. Extruded corn and soybeans were processed according to the procedure described by Friesen et al. (1993). All ingredients were used in 3 calf starters within the same lots.

\section{Animal Housing and Management}

The experiments were conducted under the approval of China Agricultural University Animal Science and Technology College Animal Care and Use Committee (Beijing). Calves were housed in naturally ventilated barns in individual pens $(1.5 \times 3.0 \mathrm{~m})$ bedded with wood shavings. Nose-to-nose contact between calves was minimized by pen arrangement. Milk was provided in 3 equal feeding intervals per day at $10 \%$ of initial BW at 0600, 1300, and $2000 \mathrm{~h}$ and gradually decreased with the increased calf starter intake; the milk amount allowance was gradually reduced at a level of about 0.25 to $0.5 \mathrm{~kg} /$ calf every $3 \mathrm{~d}$. Based on the calf feeding tradition in China, calf starter and hay were both offered ad libitum and intake was recorded daily. Calves were weaned when starter consumption reached 0.7 $\mathrm{kg} / \mathrm{d}$ for 2 consecutive days. Water was provided freely and changed daily.

\section{Starter Sampling and Analyses}

Three calf starter samples were collected from each commercial calf starter when new bags were opened throughout the study, ground through a 1-mm screen in a Wiley mill (Arthur H. Thomas Co., Philadelphia, $\mathrm{PA}$ ), and analyzed in triplicate for $\mathrm{DM}, \mathrm{Ca}, \mathrm{P}$, ether extract (EE; AOAC, 1990), NDF, and ADF (Van Soest et al., 1991). Crude protein was analyzed using a nitrogen analyzer (model Rapid N III, Elementar, Analysen Systeme GmbH, Germany) based on the Dumas combustion method (AOAC, 1990). Starch was determined according to Xiong et al. (1991). Values for total digestible nutrients, $\mathrm{NE}_{\mathrm{M}}$, and $\mathrm{NE}_{\mathrm{G}}$ were calculated based on the NRC (2001) model.

\section{Calf Health Monitoring and Experimental Measurement}

Calf health was monitored each day using the procedure of Larson et al. (1977). Body weight, withers height (WH), hip height (HH), hip width (HW), and heart girth (HG) were measured at $3,4,5,6,7,9,11$, and 13 wk of age. Blood samples were collected on the same sampling day within 30 min postprandial to the a.m. feeding via jugular venipuncture into evacuated tubes containing EDTA. One of the blood sampling tubes was collected for measurement of hematocrit (HEM) by microhematocrit centrifuge. The other tubes were centrifuged for $10 \mathrm{~min}$ at $1,600 \times g$ for plasma separation. The plasma was frozen $\left(-20^{\circ} \mathrm{C}\right)$ until analyzed for BHBA acid, glucose, and NEFA. Plasma BHBA was determined using the Stanbio BHBA LiquiColor kit (procedure no. 2440, Stanbio Laboratory, Boerna, TX). Plasma glucose was determined using a glucose kit (number 510, Sigma-Aldrich Chemical Co., St. Louis, MO).

\section{Statistical Analysis}

Initial BW, WH, HH, HW, and HG were analyzed as a completely randomized design by ANOVA (SAS Institute, Cary, NC). Parameters taken at weaning and at the end of the study were analyzed as described by Lesmeister and Heinrichs (2004) but without block effects.

Blood variables (HEM, BHBA, glucose, and NEFA), ADG, and DMI were analyzed by MIXED procedures 
Table 1. Ingredients of calf starter containing ground (GCS), steam-flaked (SFCS), or extruded (ECS) corn and soybeans

\begin{tabular}{|c|c|c|c|}
\hline \multirow[b]{2}{*}{ Ingredient ( $\%$ of starter DM) } & \multicolumn{3}{|c|}{ Calf starter } \\
\hline & GCS & SFCS & ECS \\
\hline Whole corn & 45.5 & - & - \\
\hline Steam-flaked corn & - & 45.5 & - \\
\hline Extruded corn & - & - & 45.5 \\
\hline $\mathrm{DDGS}^{1}$ & 16.0 & 16.0 & 16.0 \\
\hline Soybean hulls & 3.0 & 3.0 & 3.0 \\
\hline Wheat bran & 1.0 & 1.0 & 1.0 \\
\hline Apple pulp & 1.5 & 1.5 & 1.5 \\
\hline Cottonseed meal & 6.5 & 6.5 & 6.5 \\
\hline Raw full-fat soybeans & 7.3 & - & - \\
\hline Steam-flaked full-fat soybeans & - & 7.3 & - \\
\hline Extruded full-fat soybeans & - & - & 7.3 \\
\hline Brewers dried grain & 14.0 & 14.0 & 14.0 \\
\hline Fine limestone & 1.5 & 1.5 & 1.5 \\
\hline Dicalcium phosphate & 1.1 & 1.1 & 1.1 \\
\hline Salt & 0.8 & 0.8 & 0.8 \\
\hline $1 \%$ cobalt chloride & 0.014 & 0.014 & 0.014 \\
\hline $5 \%$ urease inhibitor & 0.14 & 0.14 & 0.14 \\
\hline Flavor promoter & 0.0028 & 0.0028 & 0.0028 \\
\hline Zinc sulfate & 0.035 & 0.035 & 0.035 \\
\hline Ferric sulfate & 0.014 & 0.014 & 0.014 \\
\hline Copper sulfate & 0.0175 & 0.0175 & 0.0175 \\
\hline Manganese sulfate & 0.042 & 0.042 & 0.042 \\
\hline $5 \%$ potassium iodide & 0.007 & 0.007 & 0.007 \\
\hline Sodium selenite & 0.014 & 0.014 & 0.014 \\
\hline Rare earth & 0.028 & 0.028 & 0.028 \\
\hline $17 \%$ zinc proteinate & 0.007 & 0.007 & 0.007 \\
\hline Bentonite & 0.14 & 0.14 & 0.14 \\
\hline Zeolite powder & 0.2387 & 0.2387 & 0.2387 \\
\hline Vitamin $\mathrm{A}^{2}$ & 0.0028 & 0.0028 & 0.0028 \\
\hline $50 \%$ vitamin $\mathrm{E}$ & 0.014 & 0.014 & 0.014 \\
\hline Vitamin $\mathrm{D}^{3}$ & 0.0007 & 0.0007 & 0.0007 \\
\hline Nicotinic acid & 0.0035 & 0.0035 & 0.0035 \\
\hline Bentonite & 0.049 & 0.049 & 0.049 \\
\hline Diamond V XP 4 & 0.48 & 0.48 & 0.48 \\
\hline Dynamate $^{5}$ & 0.1 & 0.1 & 0.1 \\
\hline Magnesium oxide & 0.4 & 0.4 & 0.4 \\
\hline Luctarom sucklers $^{6}$ & 0.05 & 0.05 & 0.05 \\
\hline \multicolumn{4}{|c|}{${ }^{1}$ DDGS $=$ dehydrated distillers grains with solubles. } \\
\hline \multicolumn{4}{|c|}{${ }^{2} 500,000 \mathrm{IU} / \mathrm{kg}$. } \\
\hline \multicolumn{4}{|l|}{${ }^{3} 500,000 \mathrm{IU} / \mathrm{kg}$. } \\
\hline \multicolumn{4}{|c|}{$\begin{array}{l}{ }^{4} \text { Diamond V XP (Diamond V Mills, Cedar Rapids, IA): Saccharomyces cerevisiae yeast and the media on which } \\
\text { it was grown consisting of ground yellow corn, hominy feed, corn gluten feed, wheat middlings, rye middlings, } \\
\text { diastatic malt and corn syrup, and cane molasses. }\end{array}$} \\
\hline \multicolumn{4}{|c|}{$\begin{array}{l}{ }^{5} \text { Dynamate (Mosaic Co., Plymouth, MN): Potassium and magnesium sulfate; typical chemical composition is } \\
\mathrm{S} 22.20 \%, \mathrm{~K} 18.40 \%, \mathrm{Mg} 11.10 \%, \mathrm{Cl} 1.25 \%, \mathrm{Fe} 0.06 \% \text {, Na } 0.78 \%, \mathrm{Ca} 0.22 \%, \mathrm{Mn} 25.00 \mathrm{mg} / \mathrm{kg}, \mathrm{Zn} 5.00 \mathrm{mg} / \mathrm{kg} \text {, } \\
\text { Mo }<1.00 \mathrm{mg} / \mathrm{kg}, \mathrm{Cu} 69.00 \mathrm{mg} / \mathrm{kg} \text {, Co }<1.00 \mathrm{mg} / \mathrm{kg} \text {, and Se } 5.00 \mathrm{mg} / \mathrm{kg} \text {. }\end{array}$} \\
\hline \multicolumn{4}{|c|}{$\begin{array}{l}{ }^{6} \text { Luctarom sucklers (Lucta S. A., Barcelona, Spain): Feed flavor enhancement. The ingredients were a mixture } \\
\text { of natural aromatic products and their corresponding synthetic products. }\end{array}$} \\
\hline
\end{tabular}

of SAS (SAS Institute) using repeated measures with the model

$$
\mathrm{Y}_{\mathrm{ijk}}=\mu+\mathrm{T}_{\mathrm{i}}+\mathrm{C}_{(\mathrm{i}) \mathrm{j}}+\mathrm{P}_{\mathrm{k}}+(\mathrm{TP})_{\mathrm{ik}}+\mathrm{e}_{(\mathrm{ijk})}
$$

where $\mathrm{Y}_{\mathrm{ijk}}=$ dependent variable, $\mu=$ overall mean, $\mathrm{T}_{\mathrm{i}}$ $=$ treatment $\mathrm{i}, \mathrm{C}_{(\mathrm{i}) \mathrm{j}}=$ calf $\mathrm{j}$ within treatment $\mathrm{i}, \mathrm{P}_{\mathrm{k}}=$ time period $\mathrm{k},(\mathrm{TP})_{\mathrm{ik}}=$ treatment $\times$ period interaction, and $\mathrm{e}_{(\mathrm{ijk})}=$ residual. The term $\mathrm{C}_{(\mathrm{i}) \mathrm{j}}$ was used as error to test differences because of treatments. Significance was declared as $P<0.05$ unless noted otherwise.

\section{RESULTS AND DISCUSSION}

\section{Dietary Composition}

Nutrient composition of calf starter is presented in Table 2. Though the ingredients over the whole experi- 
Table 2. Nutrient composition of calf starter containing ground (GCS), steam-flaked (SFCS), or extruded (ECS) corn and soybeans ${ }^{1}$

\begin{tabular}{lrrr}
\hline & \multicolumn{3}{c}{ Calf Starter } \\
\cline { 2 - 4 } Item $(\% \text { unless noted })^{2}$ & GCS & SFCS & \multicolumn{1}{c}{ ECS } \\
\hline $\mathrm{DM}$ & 89.26 & 90.20 & 91.14 \\
$\mathrm{TDN}$ & 78.46 & 79.74 & 78.30 \\
$\mathrm{NE}_{\mathrm{M}}(\mathrm{Mcal} / \mathrm{kg})$ & 1.98 & 2.01 & 1.98 \\
$\mathrm{NE}_{\mathrm{G}}(\mathrm{Mcal} / \mathrm{kg})$ & 1.34 & 1.38 & 1.34 \\
$\mathrm{CP}$ & 21.45 & 21.05 & 18.87 \\
Starch & 38.45 & 38.08 & 38.58 \\
$\mathrm{Crude}$ fat & 5.03 & 3.88 & 3.39 \\
$\mathrm{NDF}$ & 32.44 & 32.54 & 34.98 \\
$\mathrm{ADF}$ & 18.14 & 18.25 & 20.24 \\
$\mathrm{Ca}$ & 1.33 & 1.21 & 1.20 \\
$\mathrm{P}$ & 0.67 & 0.67 & 0.62 \\
Crude ash & 8.23 & 7.98 & 7.67 \\
\hline
\end{tabular}

${ }^{1}$ Means of 3 observations from 3 samples per treatment starter.

${ }^{2}$ Total digestible nutrients $(\mathrm{TDN}), \mathrm{NE}_{\mathrm{M}}$, and $\mathrm{NE}_{\mathrm{G}}$ were derived from NRC (2001).

ment were from the same purchase batches for 3 calf starters by design (Table 1), a lower $\mathrm{CP}$ and a higher NDF and ADF were observed in the ECS starter compared with the GCS starter. As an effective heating treatment method, extrusion can provide an extensive heat-denatured effect on the protein materials (Wang et al., 2004). A similar result was reported by Faldet et al. (1992) in which the diet containing extruded soybeans had lower CP content than the diet containing raw soybeans ( $37.2 \%$ vs. $35.9 \%)$. The reduced CP content of protein feeds caused by extrusion did not occur in steam-flaked soybeans (Table 1). We also observed reduced EE content after heat processing occurring in SFCS and ECS starter diets. Although the exact mechanism for this reduction is unknown, heat damage to lipid compositions of corn grains and soybeans during steam-flaking and extrusion is probably a major reason. Other researchers (Chouinard et al., 1997) also observed that extrusion of raw soybeans decreased EE content from $17 \%$ to $16.3 \%$. Slightly higher NDF and ADF contents in the ECS diet than in the GCS and SFCS diets were expected because of a concentrating effect from the decreased $\mathrm{CP}$ content of the former starter caused by extruding processing. No matter what changes occur during heat processing, nutrients provided by all 3 starter diets would meet the requirement of calves (NRC, 2001).

\section{Calf Health}

Calves were generally healthy throughout the trial. Least squares means for days scoured are presented in Table 3. Calves fed the ECS and GCS starters had increased scouring days and generally were not as healthy compared with calves fed the SFCS starter. This observation is inconsistent with the report of Lesmeister and Heinrichs (2004) in which no significant treatment differences for calf health were observed. The reason may be related to a relatively lower starter intake for the SFCS treatment than for the ECS and GCS treatments in the present study.

\section{Growth Performance}

Least squares means for initial, weaning, and final BW, ADG, starter intake, total DMI, and feed efficiency of the whole period are summarized in Table 3. All of the calves weaned at about wk 8 according to their starter intake. Therefore, values for ADG, starter intake, and total DMI are separately presented during the preweaning, postweaning, and overall periods. Initial BW was similar among 3 treatments and averaged $51.77,50.50$, and $49.14 \mathrm{~kg}$ for GCS, SFCS, and ECS treatments, respectively, resulting in similar fresh milk intake among treatments. Final BW did not differ significantly among treatments $(P>0.05)$. During the preweaning period, no treatment differences were detected for ADG, starter intake, or total DMI, and weaning BW was similar for all treatments. During the postweaning period, starter intakes for the SFCS treatment were relatively lower than for the GCS and ECS treatments, though they were not significantly different $(P>0.05)$. Calves fed the SFCS diet had a better overall feed efficiency compared with those fed the GCS and ECS diets $(P=0.05)$ because of relatively lower starter intake with similar BW gain. This result is inconsistent with the observation of Lesmeister and Heinrichs (2004) in which calves were weaned at 28 $\mathrm{d}$ and the feed efficiency was negatively influenced by incorporation of steam-flaking corn in the starter during postweaning wk 5 and 6 . Heat processing has been recognized to increase postruminal energy availability (Huntington, 1997; Crocker et al., 1998; Lesmeister and Heinrichs, 2004).

In addition, ADG was influenced by week of the treatment $(P<0.05$; Figure 1$)$. Daily gain was generally decreased during the weaning period (around wk 8; $574.49 \mathrm{~g} / \mathrm{d}$ ) compared with the preweaning (912.41 $\mathrm{g} / \mathrm{d})$ and postweaning $(963.78 \mathrm{~g} / \mathrm{kg})$ weeks. Compared with ADG data from Lesmeister and Heinrichs (2004) using the texturized calf starter, preweaning ADG from this study was higher but postweaning ADG was similar. The difference in ADG between both studies may be attributed to the difference in physical form of calf starters (pelleted and texturized) and feed intake (higher in this study) between 2 the studies. 


\section{Body Structural Change}

Least squares means for initial, final, and average daily change of $\mathrm{HH}, \mathrm{WH}, \mathrm{HW}$, and $\mathrm{HG}$ are presented in Table 4. Heat processing of starter corn and soybeans had no significant $(P>0.05)$ effect on all of the structural growth traits ( $\mathrm{HH}, \mathrm{WH}, \mathrm{HW}$, and $\mathrm{HG}$ ). This result is consistent with the previous report with processed sorghum in which calves offered steam-flaked sorghum starter had no differences in growth rate but tended to have higher grain intake (Schun et al., 1970; Abdelgadir and Morrill, 1995).

\section{Blood Parameters}

Blood HEM was significantly $(P<0.01)$ affected by starter treatment and by weeks of treatment (Figure 2 ), although the trends of change were different. The HEM for the SFCS treatment was the lowest at wk 3 and increased to the highest at wk 9 , then decreased for all treatments. There was a higher $(P<0.05)$ blood HEM for the SFCS treatment than for the other 2 treatments from wk 6 to 13 . This result was inconsistent with the observation of Lesmeister and Heinrichs
(2004) in which no treatment effects for HEM were measured over time. Adams et al. (1993) suggested that calves with lower hematological variables had higher mortality rates because of the difficulty in maintaining normal body temperature. Therefore, the higher HEM resulting from the SFCS treatment than from the other 2 starter treatments suggests that calves receiving the SFCS starter have better health conditions than those receiving the other 2 treatments.

The concentration of blood BHBA was significantly different $(P<0.05)$ among 3 starter treatments throughout the 10 -wk trial except wk 3 and 6 . A significant $(P$ $<0.05$ ) interaction between week and treatment indicated that magnitude of differences among 3 starter treatments varied with treatment time. As indicated in Figure 3, calves fed the SFCS starter had higher concentrations of blood BHBA than those fed the GCS and ECS starters, especially in the period of wk 3 to 6 . The concentration of blood BHBA fluctuated within the average range values before weaning, increased markedly from wk 6 to 9, and finally kept constant after wk 9. During wk 6 to 9, calves fed the SFCS and GCS diets had higher BHBA concentrations, though DM feed intake was similar. This result is inconsistent

Table 3. Least squares means for BW, ADG, DMI, and days scoured of Holstein calves receiving calf starter containing ground (GCS), steam-flaked (SFCS), or extruded (ECS) corn and soybeans ${ }^{1}$

\begin{tabular}{|c|c|c|c|c|c|}
\hline \multirow[b]{2}{*}{ Item } & \multicolumn{3}{|c|}{ Calf starter } & \multirow[b]{2}{*}{ SEM } & \multirow[b]{2}{*}{$P$-value } \\
\hline & GCS & SFCS & ECS & & \\
\hline \multicolumn{6}{|l|}{ BW (kg) } \\
\hline Initial & 51.77 & 50.50 & 49.14 & 2.247 & NS \\
\hline Weaning & 76.76 & 76.27 & 75.03 & 2.782 & NS \\
\hline Final & 114.10 & 108.59 & 110.16 & 4.115 & NS \\
\hline \multicolumn{6}{|l|}{ ADG (g/d) } \\
\hline Preweaning & 892.4 & 920.4 & 924.5 & 33.9 & NS \\
\hline Postweaning $^{2}$ & 889.1 & 769.4 & 843.5 & 52.5 & NS \\
\hline Overall periods & 890.4 & 829.8 & 875.9 & 38.7 & NS \\
\hline \multicolumn{6}{|l|}{ DMI (g/d) } \\
\hline Milk & 860.2 & 850.7 & 823.1 & 30.71 & NS \\
\hline \multicolumn{6}{|l|}{ Starter } \\
\hline Preweaning & 117.2 & 111.9 & 156.1 & 23.3 & NS \\
\hline Postweaning & $2,031.9$ & $1,802.6$ & $2,008.2$ & 114.8 & NS \\
\hline Overall periods & $1,266.0$ & $1,126.3$ & $1,267.4$ & 73.4 & NS \\
\hline \multicolumn{6}{|l|}{ Hay } \\
\hline Overall periods & 189.9 & 168.9 & 190.1 & 11.0 & NS \\
\hline \multicolumn{6}{|l|}{ Total DMI } \\
\hline Preweaning & $1,034.8$ & $1,015.2$ & $1,036.8$ & 43.6 & NS \\
\hline Postweaning & $2,370.7$ & $2,111.2$ & $2,343.1$ & 129.5 & NS \\
\hline Overall periods & $1,836.4$ & $1,672.8$ & $1,820.6$ & 88.1 & NS \\
\hline Feed efficiency ${ }^{3}$ & $0.529^{\mathrm{b}}$ & $0.562^{\mathrm{a}}$ & $0.538^{\mathrm{b}}$ & 0.023 & 0.05 \\
\hline Days scoured $^{4}$ & $3.7^{\mathrm{a}}$ & $2.0^{\mathrm{b}}$ & $3.5^{\mathrm{a}}$ & 1.46 & 0.01 \\
\hline
\end{tabular}

${ }^{\mathrm{a}, \mathrm{b}}$ Means within a row without a common superscript letter differ $(P<0.05)$.

${ }^{1}$ All of the data for each index were sampled from 10 calves.

${ }^{2}$ The decrease of ADG was probably caused by the transition from milk.

${ }^{3}$ Expressed as a ratio of kilograms of gain to kilograms of total DMI.

${ }^{4}$ Days with feces scores of 3 (runny) or 3 (runny) and 4 (watery); Larson et al. (1977).

$\mathrm{NS}=P>0.05$. 
Table 4. Least squares means for structural growth measurements of Holstein calves receiving calf starter containing ground (GCS), steam-flaked (SFCS), or extruded (ECS) corn and soybeans ${ }^{1}$

\begin{tabular}{|c|c|c|c|c|c|}
\hline \multirow[b]{2}{*}{ Item } & \multicolumn{3}{|c|}{ Calf starter } & \multirow[b]{2}{*}{ SEM } & \multirow[b]{2}{*}{$P$-value } \\
\hline & GCS & SFCS & ECS & & \\
\hline \multicolumn{6}{|l|}{ Hip height } \\
\hline Initial (cm) & 75.71 & 75.14 & 76.71 & 1.501 & $\mathrm{NS}^{1}$ \\
\hline Final $(\mathrm{cm} 0$ & 88.86 & 88.29 & 90.14 & 1.131 & NS \\
\hline Change $(\mathrm{cm} / \mathrm{d})$ & 0.188 & 0.188 & 0.192 & 0.014 & NS \\
\hline \multicolumn{6}{|l|}{ Wither height } \\
\hline Initial $(\mathrm{cm})$ & 80.43 & 80.14 & 80.86 & 1.160 & NS \\
\hline Final $(\mathrm{cm})$ & 98.00 & 96.71 & 99.14 & 1.426 & NS \\
\hline Change, $\mathrm{cm} / \mathrm{d}$ & 0.251 & 0.237 & 0.261 & 0.015 & NS \\
\hline \multicolumn{6}{|l|}{ Hip width } \\
\hline Initial (cm) & 9.857 & 10.286 & 9.357 & 0.374 & NS \\
\hline Final $(\mathrm{cm})$ & 12.714 & 12.857 & 12.643 & 0.181 & NS \\
\hline Change $(\mathrm{cm} / \mathrm{d})$ & 0.041 & 0.037 & 0.047 & 0.005 & NS \\
\hline \multicolumn{6}{|l|}{ Heart girth } \\
\hline Initial (cm) & 88.43 & 86.57 & 87.14 & 1.432 & NS \\
\hline Final $(\mathrm{cm})$ & 112.57 & 109.86 & 111.29 & 1.496 & NS \\
\hline Change $(\mathrm{cm} / \mathrm{d})$ & 0.345 & 0.333 & 0.345 & 0.019 & NS \\
\hline
\end{tabular}

${ }^{1}$ All of the data for each index were sampled from 10 calves.

$\mathrm{NS}=P>0.05$.

with the observation of Quigley et al. (1991), indicating that an increase in blood BHBA is closely related to availability of calf starter. The BHBA concentrations in calves fed the SFCS and GCS starters increased dramatically from $0.135 \mathrm{mmol} / \mathrm{L}$ to $0.344 \mathrm{mmol} / \mathrm{L}$ during wk 6 to 9 , whereas BHBA concentrations in calves fed the ECS starter increased from $0.140 \mathrm{mmol} / \mathrm{L}$ to 0.253 $\mathrm{mmol} / \mathrm{L}$.

The concentration of plasma glucose (Figure 4) decreased significantly with advancing age of calves. The concentration was characteristic of nonruminants $(248.3 \mathrm{mg} / \mathrm{dL})$, but reached a nadir at $54.44 \mathrm{mg} / \mathrm{d}$ from wk 9 to 13 in this study. The difference among weeks reflected a difference in feed intake, especially from wk 3 to 8. Plasma glucose approached a concentration typical of mature ruminants (Swenson, 1984) during the postweaning period and did not differ among treatments. When compared among weeks, no significant difference $(P>0.05)$ except wk 11 was observed for plasma glucose concentration among starter treatments. Because blood samples were taken within 30 min after the a.m. feeding, this result cannot reflect the development of ruminal functions (Reid, 1953).

The concentration of plasma NEFA was not significantly affected by starter treatments within preweaning (wk 3-4) and postweaning (wk 11-13) periods, but was

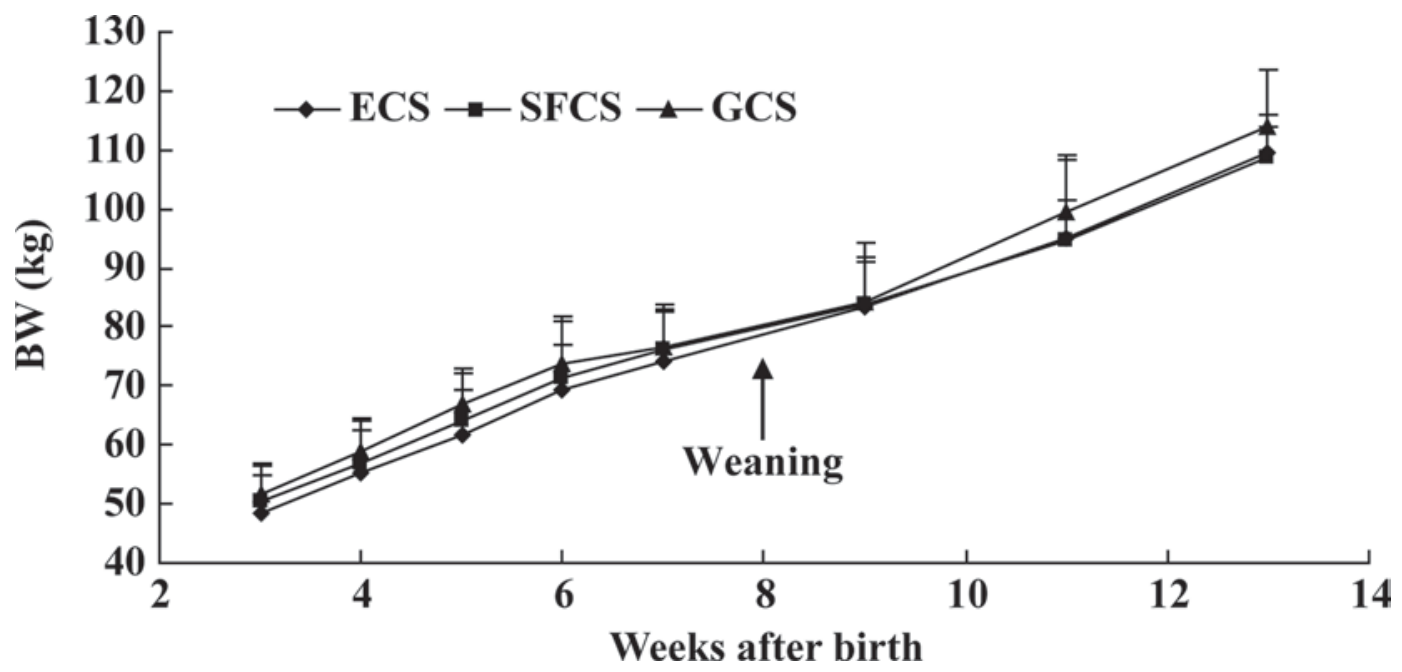

Figure 1. Least squares means for BW of Holstein calves receiving calf starter containing ground (GCS), steam-flaked (SFCS), or extruded (ECS) corn and soybeans. 


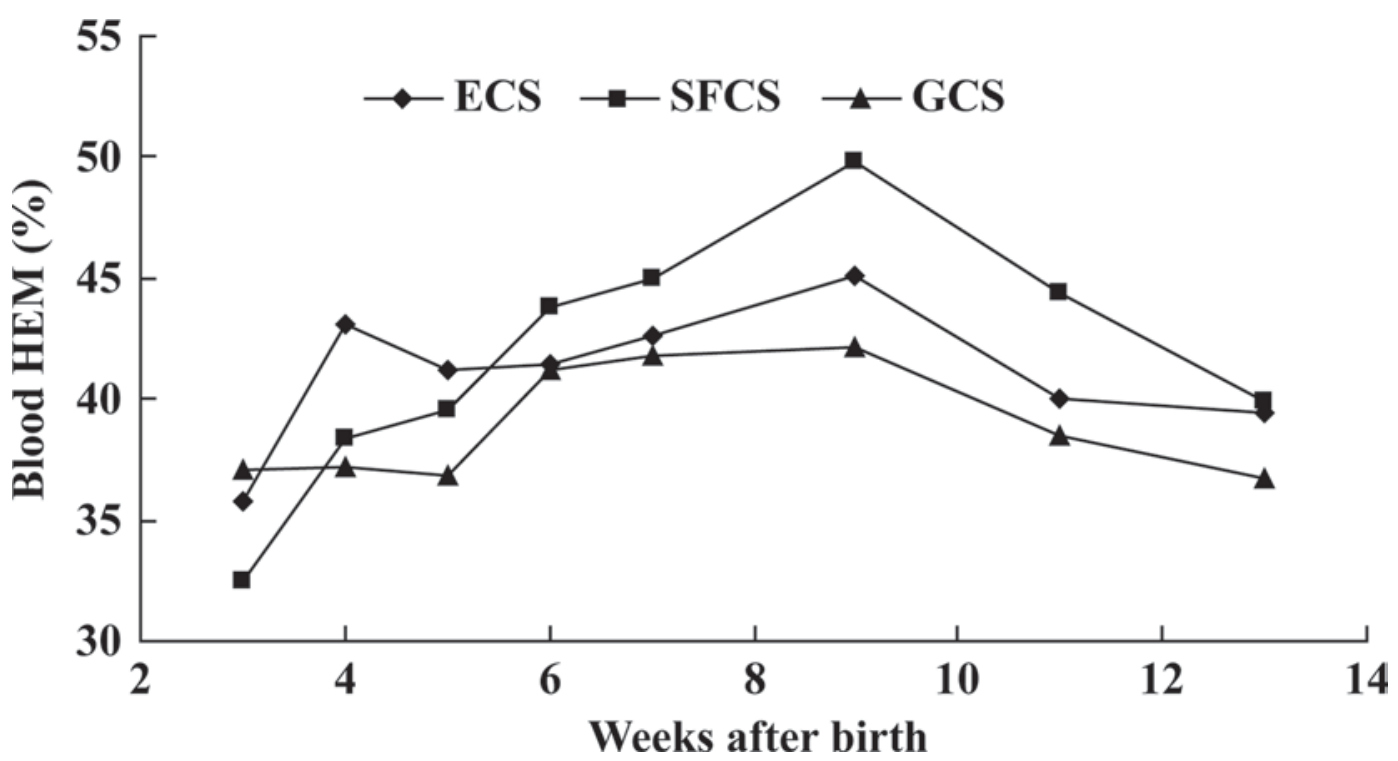

Figure 2. Least squares means for blood hematocrit (HEM) of Holstein calves receiving calf starter containing ground (GCS), steam-flaked (SFCS), or extruded (ECS) corn and soybeans.

higher $(P<0.05)$ in calves receiving the SFCS treatment during wk 5 to 9 . Average concentration of NEFA in calves fed the GCS, SFCS, and ECS starters was $368.54,505.08$, and $322.73 \mu \mathrm{Eq} / \mathrm{L}$, respectively, during wk 5 to 8 . The plasma NEFA was affected by treatment weeks (Figure 5) and increased from $291.71 \mu \mathrm{Eq} / \mathrm{L}$ at wk 3 to $432.02 \mu \mathrm{Eq} / \mathrm{L}$ at wk 5 , decreased to 183.88 $\mu \mathrm{Eq} / \mathrm{L}$ at wk 11, and did not differ thereafter. These results were consistent with those reported for mature ruminants (Kronfeld, 1965) and lambs (Leat, 1967), but higher than those reported for sheep (Trenkle and
Kuhlemeier, 1966) sampled within $4 \mathrm{~h}$ of feeding. The sampling time may affect NEFA concentrations because NEFA is sensitive to plasma glucose and VFA (Trenkle and Kuhlemeier, 1966). During wk 5 to 9, NEFA in calves fed the SFCS starter was higher than in those fed the other 2 treatments.

The correlations among selected blood parameters and starter intake in this study are summarized in Table 5. Significant correlations of glucose with starter intake $(\mathrm{r}=-0.71)$ support the viewpoint of Quigley et al. (1991) that early weaning has a significant effect

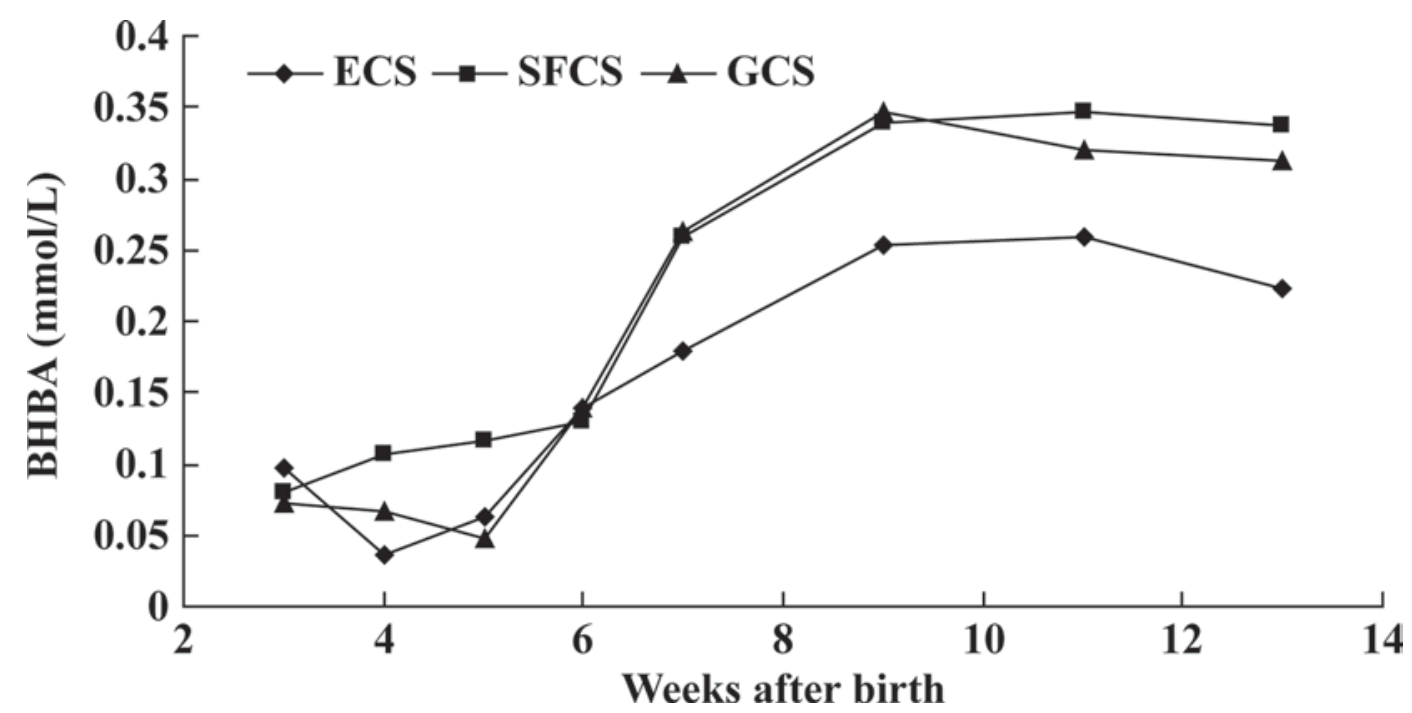

Figure 3. Least squares means for blood BHBA of Holstein calves receiving calf starter containing ground (GCS), steam-flaked (SFCS), or extruded (ECS) corn and soybeans. 


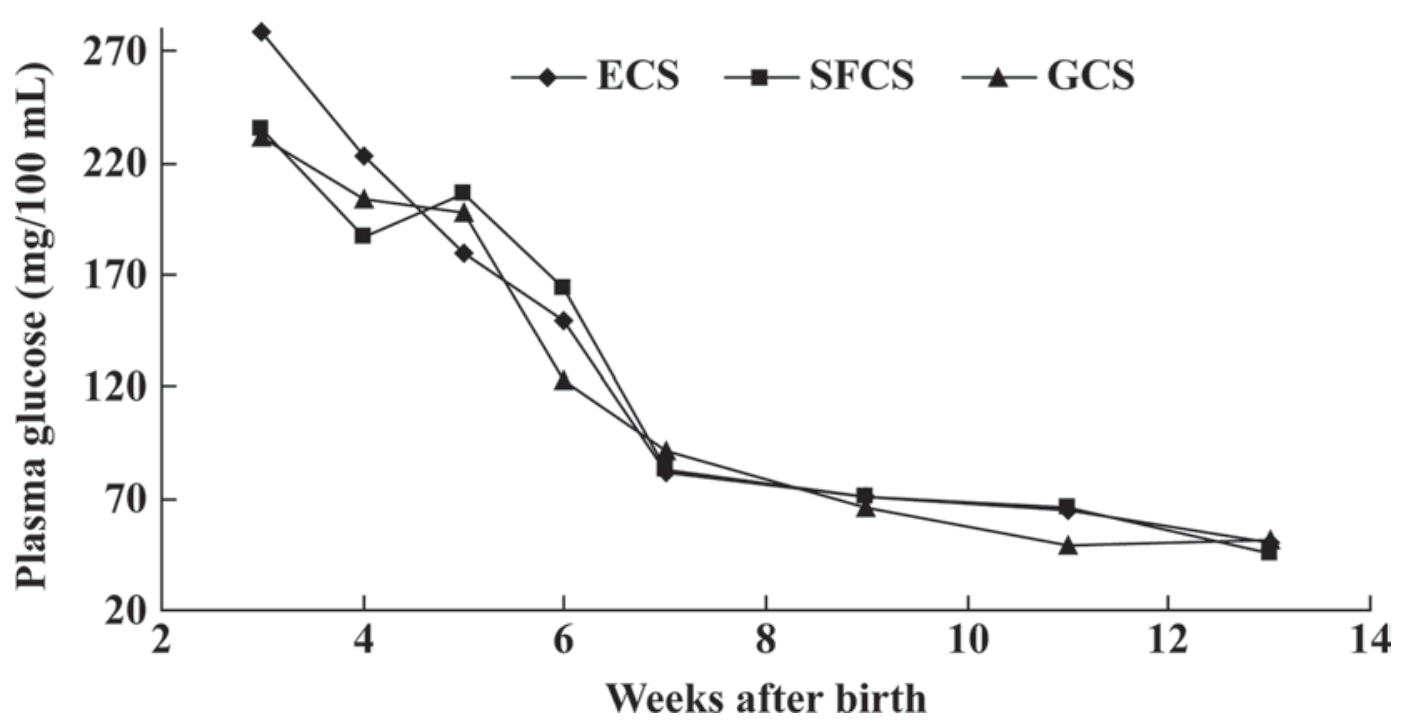

Figure 4. Least squares means for plasma glucose of Holstein calves receiving calf starter containing ground (GCS), steam-flaked (SFCS), or extruded (ECS) corn and soybeans.

on plasma glucose concentration in so far as source of glucose is altered. Relationship between plasma glucose and NEFA concentrations $(r=0.22)$ is significant, suggesting that changes in plasma glucose may have induced concomitant changes in NEFA throughout the study. This result was consistent with the report of Trenkle and Kuhlemeier (1966).

\section{CONCLUSIONS}

Steam-flaked corn and soybeans included in the calf starter had no effect on ADG, BW, DMI, and calf body structural growth compared with GCS and ECS, but feed efficiency was improved by SFCS. Calf starter intake for the SFCS treatment was numerically lower but did not differ significantly from the GCS and ECS treatments. Based on disease incidences, there were indications that feeding SFCS improved calf health compared with the other starter treatments. The performance of all calves in 3 treatments fell in the normal range with the variation of some blood parameters. All of the selected blood parameters changed with the calves' age, indicating the transition from neonatal calf stage to mature ruminant. The differences in HEM, BHBA,

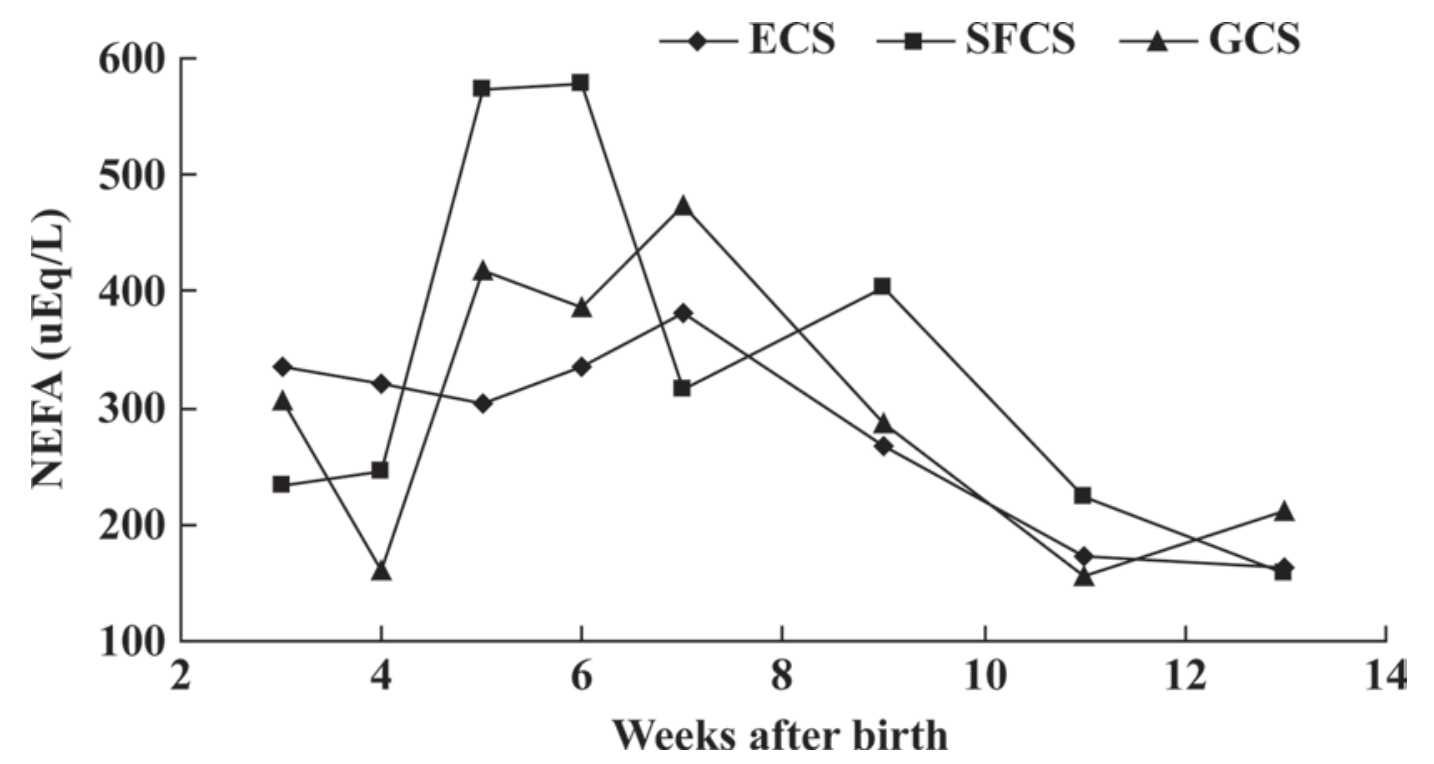

Figure 5. Least squares means for plasma NEFA of Holstein calves receiving calf starter containing ground (GCS), steam-flaked (SFCS), or extruded (ECS) corn and raw soybeans. 
Table 5. Coefficients ${ }^{1}$ of correlation of starter intake (SI), blood hematocrit (HEM), blood BHBA, plasma glucose (GLU), and plasma NEFA

\begin{tabular}{lcccc}
\hline Item & HEM & BHBA & GLU & NEFA \\
\hline SI & $-0.199^{*}$ & 0.567 & -0.712 & -0.501 \\
HEM & & 0.287 & -0.358 & $0.193^{*}$ \\
BHBA & & & -0.742 & $-0.070^{* *}$ \\
GLU & & & & 0.219 \\
\hline
\end{tabular}

${ }^{1}$ All coefficients are significant $(P<0.05)$ except data with an asterisk.

${ }^{*} P<0.10 ;{ }^{*} P>0.10$.

and NEFA concentrations among treatments indicated that calf metabolism is influenced by heat processing of corn grain and soybeans. These data suggest that the steam-flaking of corn and soybeans can influence the growth performance and selected blood parameters of calves and that, in this study, the extrusion of corn and soybeans had no beneficial effect on growth performance of calves.

\section{ACKNOWLEDGMENTS}

This study was financially supported by China National Supporting Project (No. 2008BADA7B04 and 2007BAD56B04) and Doctorial Fund of Shanxi Agricultural Science Academy (No. YBSJJ0901). The authors thank the crew of Beijing Huachen Dairy Farm (Shunyi, Beijing, China) for their input on this study.

\section{REFERENCES}

Abdelgadir, I. E. O., and J. L. Morrill. 1995. Effect of processing sorghum grain on dairy calf performance. J. Dairy Sci. 78:20402046.

Adams, R., F. B. Garry, B. M. Aldridge, M. D. Holland, and K. G. Odde. 1993. Physiologic differences between twin and single born beef calves in the first two days of life. Cornell Vet. 83:13-29.

Association of Official Analytical Chemists. 1990. Official Methods of Analysis. 15th ed. AOAC, Washington, DC.

Chouinard, P. Y., J. Lévesque, V. Girard, and G. J. Brisson. 1997. Dietary soybeans extruded at different temperatures: Milk composition and in situ fatty acid reactions. J. Dairy Sci. 80:2913-2924.

Crocker, L. M., E. J. DePeters, J. G. Fadel, H. Perez-Monti, S. J. Taylor, J. A. Wyckoff, and R. A. Zinn. 1998. Influence of processed corn grain in diets of dairy cows on digestion of nutrients and milk composition. J. Dairy Sci. 81:2394-2407.

Faldet, M. A., Y. S. Son, and L. D. Saiter. 1992. Chemical, in vitro, and in vivo evaluation of soybeans heat-treated by various processing methods. J. Dairy Sci. 75:789-795.
Friesen, K. G., J. L. Nelssen, R. D. Goodband, K. C. Behnke, and L. J. Kats. 1993. The effect of moist extrusion of soy products on growth performance and nutrient utilization in the early-weaned pig. J. Anim. Sci. 71:2099-2109.

Harrison, H. N., R. G. Warner, E. C. Sander, and J. K. Loosli. 1960. Changes in the tissue and volume of the stomachs of calves following the removal of dry feed or consumption of inert bulk. J. Dairy Sci. 43:1301-1312.

Huntington, G. B. 1997. Starch utilization by ruminants: From basics to the bunk. J. Anim. Sci. 75:852-867.

Kronfeld, D. S. 1965. Plasma nonesterified fatty acid concentrations in the dairy cow: Responses to nutritional and hormonal stimuli, and significance in ketosis. Vet. Rec. 77:30-35.

Larson, L. L., F. G. Owens, J. L. Albright, R. D. Appleman, R. C. Lamb, and L. D. Muller. 1977. Guidelines toward more uniformity in measuring and reporting calf experimental data. J. Dairy Sci. 60:989-991.

Leat, W. M. 1967. Plasma lipid of newborn and adult ruminants and of lambs from birth to weaning. J. Agric. Sci. (Camb.) 69:241-246.

Lesmeister, K. E., and A. J. Heinrichs. 2004. Effects of corn processing on growth characteristics, rumen development, and rumen parameters in neonatal dairy calves. J. Dairy Sci. 87:3439-3450.

NRC. 2001. Nutrient Requirements of Dairy Cattle. 7th rev. ed. Natl. Acad. Sci., Washington, DC.

Owens, F. N., D. S. Secrist, W. J. Hill, and D. R. Gill. 1997. The effect of grain source and grain processing on performance of feedlot cattle: A review. J. Anim. Sci. 75:868-879.

Quigley, J. D. III, L. A. Caldwell, G. D. Sinks, and R. N. Heitmann. 1991. Changes in blood glucose, nonesterified fatty acids, and ketones in response to weaning and feed intake in young calves. J. Dairy Sci. 74:250-257.

Reid, R. L. 1953. Studies on the carbohydrate metabolism of sheep. VI. Interrelationships between changes in the distribution and levels of glucose and in the levels of volatile fatty acids in the blood of lambs. Aust. J. Agric. Res. 4:213-223.

Reis, R. B., and D. K. Combs. 2000. Effects of corn processing and supplemental hay on rumen environment and lactation performance of dairy cows grazing grass-legume pasture. J. Dairy Sci. 83:25292538 .

Schun, J. D., J. O. A. Lima, W. H. Hale, and B. Theurer. 1970. Steamprocessed flaked grains versus steam-rolled grains for dairy calves. J. Dairy Sci. 53:475-479.

Swenson, M. J. 1984. Blood circulation and the cardiovascular system. Page 15 in Duke's Physiology of Domestic Animals. 10th ed. M. J. Swenson, ed. Cornell Univ. Press, Ithaca, NY.

Trenkle, A., and K. B. Kuhlemeier. 1966. Relationship of rumen volatile fatty acids, blood glucose, and plasma nonesterified fatty acids in sheep. J. Anim. Sci. 24:1111-1115.

Van Soest, P. J., J. B. Robertson, and B. A. Lewis. 1991. Methods for dietary, neutral detergent fiber, and non-starch polysaccharides in relation to animal nutrition. J. Dairy Sci. 74:3583-3597.

Vazquez-Anon, M., A. J. Heinrichs, J. M. Aldrich, and G. A. Varga. 1993. Postweaning age effects on rumen fermentation end-products and digesta kinetics in calves weaned at 5 weeks of age. J. Dairy Sci. 76:2742-2748.

Wang, H., L. A. Johnson, and T. Wang. 2004. Preparation of soy protein concentrate and isolate from extruded-expelled soybean meals. J. Am. Oil Chem. Soc. 81:713-717.

Xiong, Y., S. J. Bartle, and R. L. Preston. 1991. Density of steam flaked sorghum grain, roughage level, and feeding regimen for feedlot steers. J. Anim. Sci. 69:1707-1718. 